\title{
Insulin-Like Growth Factor Binding Protein-2: A Possible Regulator of Invasive Growth in Glioblastoma
}

\author{
Tsuyoshi Fukushima and Hiroaki Kataoka \\ Section of Oncopathology and Regenerative Biology, Department of Pathology, \\ Faculty of Medicine, University of Miyazaki, \\ Japan
}

\section{Introduction}

Glioblastoma is the most common malignant brain tumor and has an extremely lethal course (Clark et al., 2010). Although genetic abnormalities in p53, Akt, phosphatase and tensin homolog deleted from chromosome 10 (PTEN), and epidermal growth factor receptor that are common to various cancers are also found in glioblastoma, the prime cause of glioblastoma's malignant features and conclusive treatment targets have yet to be determined. Better understanding of non-major signal pathways involved in glioblastoma could thus provide breakthroughs in treatment strategies. Insulin-like growth factor binding protein-2 (IGFBP2) was originally reported to be a modulator of the action of insulin-like growth factors (IGFs), but IGF-independent effects of IGFBP2 on cellular proliferation, apoptosis, metabolism, and mobility have since been reported in pathological conditions, including cancers. Recent studies of gene expression microarray revealed that elevated expression of IGFBP2 occurs in gliomas, and is associated with increasing grades of malignancy with significant overexpression in glioblastomas (Fuller et al., 1999; Sallinen et al., 2000). Subsequent studies have suggested that IGFBP2 may be one of the proteins that play an important role in malignant phenotypes of glioblastoma cells (Fukushima \& Kataoka, 2007).

This chapter highlights key examples of recent biological and epidemiological research focusing on IGFBP2 in brain tumors and reviews more specialized studies on the fundamental role of IGFBP2 in glioma progression.

\section{Structure and physiological functions of IGFBP2}

\subsection{Human insulin-like growth factor binding proteins (IGFBPs)}

IGFBPs are a family of six proteins present in plasma and bodily fluids that bind insulin-like growth factor-I (IGF-I) and IGF-II with high affinity (Table 1) (Hwa et al., 1999; Firth \& Baxter, 2002; Fukushima \& Kataoka, 2007). By interacting with IGFs, the IGFBPs modulate distribution and activity of IGFs in various tissues and bodily fluids, thereby controlling their biological function in vivo (Clemmons 1998; Kelley et al., 2002). IGFBPs in IGFBP/IGF complexes can be cleaved at specific sites by various proteinases (Bunn et al., 2003). This 
IGFBP cleavage might be an important regulatory mechanism of pericellular IGF function, as IGFBP proteolysis releases IGF from the IGFBP/IGF complexes (Lee et al., 1996; Bunn et al., 2003; Fowlkes et al., 2004; Mark et al., 2005; Nakamura et al., 2005). Therefore, IGFBPs both positively and negatively regulate IGF function.

\begin{tabular}{|c|c|c|c|c|c|c|}
\hline & IGFBP1 & IGFBP2 & IGFBP3 & IGFBP4 & IGFBP5 & IGFBP6 \\
\hline Gene location & 7p13-p12 & $2 q 33-q 34$ & 7p13-p12 & $17 q 12-q 21.1$ & $2 q 33-q 36$ & $12 q 13$ \\
\hline mRNA (kbp) & 1.6 & 1.4 & 2.6 & 2.2 & 6.3 & 1 \\
\hline MW (kDa) & 25 & 31 & $43-45$ & 24 & 29 & $28-30$ \\
\hline RGD motif & $(+)$ & $(+)$ & & & & \\
\hline $\begin{array}{l}\text { Heparin } \\
\text { binding }\end{array}$ & $(+)$ & $(+)$ & $(+)$ & $(+)$ & $(+)$ & $(+)$ \\
\hline Phospho. site & $(+)$ & & $(+)$ & & $(+)$ & \\
\hline NLS & & & $(+)$ & & $(+)$ & \\
\hline $\begin{array}{l}\mathrm{N}- \\
\text { Glycosylation }\end{array}$ & & & $(+)$ & $(+)$ & & \\
\hline $\begin{array}{l}\text { O- } \\
\text { Glycosylation }\end{array}$ & & & & & $(+)$ & $(+)$ \\
\hline
\end{tabular}

Table 1. Summary of IGFBP family. MW, molecular weight of mature protein. Phosopho. site, presumed phosphorylation site. NLS, nuclear localization signal.

\subsection{Molecular properties and physiological functions of IGFBP2}

\subsubsection{Synthesis, structure and distribution of IGFBP2}

The IGFBP2 precursor is $36-\mathrm{kDa}$ (328 amino acid residues) in size and consists of a signal peptide and three distinct regions: the highly conserved N-terminal region (IGFBP homolog domain, amino acid residues 43-136); the highly conserved C-terminal region with a thyroglobulin type 1 repeat (amino acid residues 229-309); and an intervening region with four major cleavage sites (Bunn et al., 2003; Mark et al., 2005) (Figure 1). The N-terminal and C-terminal domains are cysteine-rich and globular, both of which have IGF-binding property. Mature IGFBP2 is a $31.4-\mathrm{kDa}$ protein and is the second most abundant IGFBP found in serum.

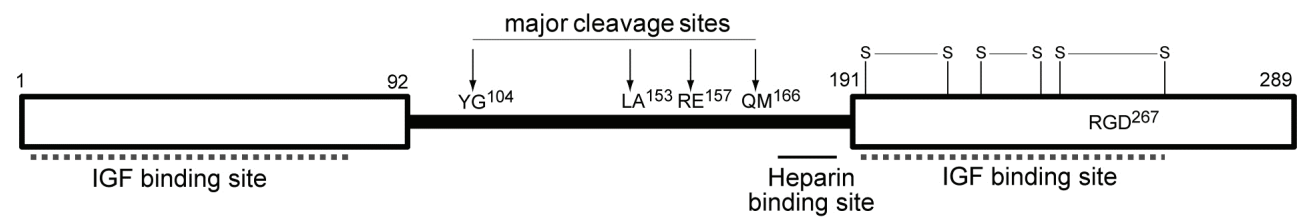

Fig. 1. Molecular structure of human IGFBP2. Amino acid positions of mature IGFBP2 protein are indicated. Integrin binding RGD motif is also shown.

Although IGFBP1, IGFBP3, and IGFBP5 each have phosphorylation sites, IGFBP2 does not. IGFBP2 does, however, have an arginine-glycine-aspartic acid (RGD) motif, which binds to cell surface integrins, and a heparin-binding domain, which facilitates association with extracellular matrices (Figure 1). Both regions are able to localize IGFBP2 and IGFBP2/IGF complexes on/around the cell surface (Schutt et al., 2004; Russo et al., 2005; Wang et al., 2006). Among the six IGFBPs, only IGFBP1 and IGFBP2 possess a RGD motif (Table 1). 
IGFBP2 is widely expressed in the fetus where its expression is reported to closely parallel that of IGF-II (Wood et al, 1992, 1993; Lee et al., 1993). IGFBP2 is predominantly expressed in the early post-implantation epiblast, the apical ectodermal ridge, the progenitors of spleen and liver, and fetal astroglial cells (Wood et al., 1992; Lee et al., 1993). Fetal epithelial cells and epidermal progenitor cells abundantly express IGFBP2, which also participates in the regulation of hair follicle development (Harris et al., 2010). The expression of IGFBP2 decreases significantly after birth, but gradually increases again, especially after the age of sixty, and found in plasma, seminal plasma, milk and cerebrospinal fluid (Blum et al., 1993; Schwander \& Mary, 1993; van den Beld et al., 2003).

\subsubsection{Regulation of IGFBP2 expression}

The IGFBP2 gene is located on chromosome 2q33-q34 near that of IGFBP5 (Garner et al., 2008). The promoter region lacks TATA box and CAAT boxes, but contains GC-rich sequences and therefore putative Sp1 binding sites. Portions of the promoter responsible for dexamethasone-induced transcriptional activity and IGF-induced stimulation of transcription have also been reported (Mouhieddine et al., 1996). Other possibly important promoter regions contain binding sites for AP-4 and nuclear factor $\mathrm{kB}$ (NF-kB) (Cazals et al., 1999). The relationship between IGFBP2 expression and loss of tumor suppressor gene function has been recently elucidated (Perks et al., 2007; Moore et al., 2009) and hypoxic microenvironment may also upregulate IGFBP2 gene expression (Feldser et al., 1999). These lines of evidence indicate that upregulated IGFBP2 gene expression should occur in injured tissue and particularly in tumors.

\subsubsection{Proposed physiological functions of IGFBP2}

By virtue of its IGF binding capacity, IGFBP2 was initially considered to be an inhibitory factor of IGFs, particularly of IGF-II with $\mathrm{K}_{\mathrm{D}}$ values for IGF-I and IGF-II to be 1.14 and 0.37, espectively (Hwa et al., 1999; Russo et al., 2005). However, it was subsequently found to prolong the half-life of IGFs. The binding between IGFs and IGFBP2 is reversible, and IGFs are released when IGFBP2 is processed at its central region cleavage sites by serine proteinases including thrombin and prostate specific antigen (human tissue kallikrein 3) (Clemmons et al., 1998; Cohen et al., 1992, Zheng et al., 1998) or matrix metalloproteinase (MMP) (Nakamura et al., 2005). As IGFBP2 can associate with cell surface integrins via its RGD motif, IGFBP2 could in theory not only be an IGF inhibitor but also provide an IGF reservoir at the cell surface to maintain efficient IGF activity in the pericellular microenvironment. Therefore, interaction between integrins and IGFBP2, cleavage of IGFBPs by proteases, and other factors that could influence the affinity of IGFBP2 for IGFs may be important regulatory mechanisms of pericellular IGF function. On the other hand, IGFBP2 has also been reported in several studies to have a cytosolic or perinuclear localization, suggesting that IGFBP2 may also have IGF-independent functions (Hoeflich et al., 2004; Fukushima \& Kataoka, 2007; Migita et al., 2010).

IGFBP2 knockout mice are both viable and fertile, and do not show significant differences in prenatal or postnatal body growth (Wood et al., 1993, 2000). However, detailed analyses of the knockout mice revealed decreased spleen weight and increased liver weight (Wood et al., 2000). Interestingly, male IGFBP2 knockout mice have shorter femurs than their control mouse counterparts, and also have significantly enhanced levels of PTEN in their 
osteoblasts and osteoclasts (DeMambro et al., 2008). Recent studies also revealed that IGFBP2 likely has a crucial regulatory role in glucose metabolism as might be expected since IGFBP2 is regulated by leptin, secreted by visceral white adipocytes, and contributes to the prevention of diet-induced obesity as well as having anti-diabetic effects (Hedbacker et al., 2010; Li \& Picard, 2010).

\section{Roles of IGFBP2 in progression of gliomas}

\subsection{Expression of IGFBP2 in tumors}

\subsubsection{Enhanced expression of IGFBP2 in malignancies of various organs}

To date, there is accumulating evidence to suggest that IGFBP2 is involved in tumor progression. Increased serum/plasma levels of IGFBP2 are associated with many malignant tumors of various organs, including prostate (Cohen et al., 1993), ovary (Lancaster et al., 2006), colon (Mishra et al., 1998), breast (Busund et al., 2005), lung (Lee et al., 1999), skin (Harris et al., 2010) and the central nervous system (Lin et al., 2009). Upregulated IGFBP2 expression levels have been reported for various tumor tissues as well, and in many instances, these expression levels correlate with the grade of malignancy (Mishira et al., 1998; Pekonen et al., 1992; Fuller et al., 1999; Rickman et al., 2001; Sallinen et al., 2000). Moreover, an inverse correlation between IGFBP2 and tumor suppressor genes, such as PTEN and p16/INK4, whose loss-of-function is frequently observed in malignant tumors, has also been reported (Perks et al., 2007; Moore et al., 2009). Indeed, induction of PTEN downregulates IGFBP2 expression in glioblastoma and prostate cancer cells (Levitt et al., 2005; Mehrian-Shai et al., 2007). On the other hand, the p53 tumor suppressor is suggested to be a transcription factor that stimulates IGFBP2 expression (Grimberg et al., 2006). Hypoxia-induced expression of IGFBP2 mediated by hypoxia inducible factor 1a (HIF1a), has also been demonstrated (Feldser et al., 1999). In sum, the expression of IGFBP2 can be significantly influenced by oncogenic genetic alteration and by a hypoxic tumor microenvironment, and many clinicopathological analyses strongly suggest that IGFBP2 participates in tumor progression.

\subsubsection{Expression of IGFBP2 in gliomas and its correlation with histological grade}

A consistent overexpression of IGFBP2 in glioblastoma was initially reported by Fuller et al. (1999) based on a gene expression profiling analysis. This finding has since been confirmed by many researchers and it is now well established that IGFBP2 expression in gliomas increases with tumor grade (Sallinen et al., 2000; Rickman et al., 2001; Elminger et al., 2001; Fukushima \& Kataoka, 2007). Indeed, IGFBP2 is one of the most powerful discriminators to distinguish glioblastomas from low-grade gliomas in proteomic analyses (Jiang et al, 2006). Regarding a possible mechanism for IGFBP2 overexpression in glioblastoma, Mehrian-Shai et al. (2007) have identified IGFBP2 as the most significant molecular signature for loss of PTEN and activation of the phosphatidylinositol 3-kinase (PI3K)/Akt pathway. Notably, glioblastoma is one of the cancers most commonly affected by PTEN abnormalities (Sulis \& Parsons, 2003). Enhanced activation of NF-kB signaling pathway in glioblastoma cells (Wang et al., 2004) may also be involved in the upregulation of IGFBP-2 transcription (Cazals et al., 1999).

The prognostic impact of IGFBPs expression in patients with newly diagnosed glioblastoma was recently reported (Santosh et al., 2010), with protein expression of IGFBP2, IGFBP 3 and 
IGFBP5 being significantly associated with shorter survival by univariate Cox regression analysis. However, multivariate Cox proportional hazards model showed that only IGFBP3 had independent prognostic impact. Plasma levels of IGFBP2 can also predict clinical outcomes of patients with glioblastoma (Lin et al., 2009). In that study, preoperative plasma IGFBP2 levels were significantly higher in high-grade glioma patients compared to lowgrade glioma patients, and are significantly correlated with recurrence and disease-free survival in glioblastoma patients.

\subsubsection{Expression of IGFBP2 in other brain tumors}

Analysis of tissue mRNA levels revealed that IGFBP2 expression is indicative of poor prognosis in patients with medulloblastoma (de Bont et al., 2008). IGFBP2 is also expressed by meningiomas, and a high IGF-II/IGFBP2 mRNA ratio is a sign of biologically aggressive behavior in meningiomas (Nordqvist et al., 1997). However, a subsequent study by the same group revealed that IGFBP6 mRNA is more informative than IGFBP2 for the evaluation of meningioma invasiveness (Nordqvist et al., 2002).

\subsection{Role of IGFBP2 in malignant progression of gliomas}

\subsubsection{Role for IGFBP2 in glioma development}

As mentioned above, analyses of clinical samples revealed that IGFBP2 expression significantly correlates with disease progression of gliomas, suggesting a role for IGFBP2 in malignant progression. Furthermore, a recent study using a glial-specific transgenic (RCAS/Ntv-a) mouse system indicated that IGFBP2 in combination with platelet-derived growth factor- $\beta$ (PDGFB) is also an oncogenic factor in glioma development (Dunlap et al., 2007). In this model, the expression of oncogenic IGFBP2 is negatively regulated by Ink4aArf, and consequently, loss of Ink4a-Arf results in enhanced IGFBP2 expression (Moore et al., 2009). Indeed, the Ink4a-Arf locus is frequently deleted in human gliomas and IGFBP2 expression is inversely correlated with p16INK4a status (Moore et al., 2009).

Evidence regarding a role for IGFBP2 in glioma development also arose from a recent study of glioma stem cell (GSC) that was found to overexpress IGFBP2, which subsequently promoted GSC expansion and survival (Hsieh et al., 2010). Notably Hedgehog-GLI1 signaling regulates human glioma growth, GSC self-renewal, and tumorigenicity (Clement et al., 2007) and gene expression of IGFs and IGFBPs is upregulated by GLI transcription factors (Villani et al., 2010). Therefore, an autocrine circuit of IGF/IGFBP2- or IGFBP2induced signaling may be established in GSCs via activation of Hedgehog-GLI1 signaling, which may contribute to the stemness of GSCs.

\subsubsection{Roles for IGFBP2 in malignant phenotypes of glioblastoma cells}

Glioblastoma is a devastating brain tumor with extremely poor prognosis (Clarke et al., 2010). Significant invasiveness into surrounding brain parenchyma, increased mitotic activity, sustained angiogenesis and necrosis surrounded by palisaded atypical tumor cells are histological hallmarks of this untreatable tumor. The major impediment to successful therapeutic intervention for glioblastomas is their diffuse invasive nature. An in vitro study using a human glioblastoma cell line engineered to overexpress IGFBP2 revealed that IGFBP2 enhances glioblastoma cell invasiveness (Wang et al., 2003). Similarly, a study using human glioblastoma cell lines in which IGFBP2 expression was knocked down by consistent 
retroviral expression of IGFBP2 short hairpin RNA (shRNA) revealed that silencing of the IGFBP2 gene reduces in vitro invasiveness and in vivo aggressiveness of the cells (Fukushima et al., 2007). Consistent with these studies, high levels of IGFBP2 expression were detected within the infiltrating tumor cells of human glioblastomas in vivo (de Groot et al., 2010). Therefore, IGFBP2 has a crucial role in glioblastoma invasion.

IGFBP2 may also be implicated in glioblastoma angiogenesis. In a cDNA-array analysis of 53 patient biopsies, IGFBP2 was included in a prominent gene cluster that allowed discrimination between primary (de novo) and non-primary (secondary) glioblastomas (Godard et al., 2003). This gene cluster is composed mostly of angiogenesis-related genes, including vascular endothelial growth factor (VEGF) and fms-related tyrosine kinase 1. Notably, in situ hybridization demonstrates coexpression of IGFBP2 and VEGF in pseudopalisading cells surrounding tumor necrosis, providing evidence for a possible involvement of IGFBP2 in angiogenesis (Godard et al., 2003). It is reasonable to postulate that HIF1a is responsible for the concomitant expression of VEGF and IGFBP2 (Carmeliet et al., 1998; Feldser et al., 1999). In addition, an anti-apoptotic function of intracellular IGFBP2 was recently reported in lung cancer cells (Migita et al., 2010), which may also have implications for the enhanced expression of IGFBP2 within glioblastoma cells around necrosis.

Taken together, these results strongly indicate that IGFBP2 has significant roles in the development of the malignant phenotypes of glioblastoma.

\subsubsection{Potential mechanisms of IGFBP2 action in the invasive growth of glioblastoma cells}

Interaction of IGFBP2 with components of the pericellular matrices results in local sequestration of IGFs and then in an enhancement of cellular IGF-induced signaling (Schutt et al., 2004). Experiments using a cultured neuroblastoma cell line showed that the heparin binding domain of IGFBP2 is required for IGFBP2 association to pericellular matrices and for IGFBP2 to promote invasive growth via efficient pericellular localization of IGF-1 (Russo et al., 2005).

However, IGF-independent actions of IGFBP2 may be equally or more important in glioblastoma biology, as has been amply demonstrated by recent research. Interaction of IGFBP2 RGD domain with integrin a5 induces outside-in signaling and may be essential for IGFBP2-induced glioma cell mobility (Wang et al., 2006). Moreover, intracellular localization of IGFBP2 has been shown in glioblastoma cells and other tumor cells such as lung carcinoma, which appears to influence the cellular gene expression signature (Fukushima \& Kataoka, 2007; Migita et al., 2010). Overexpression of IGFBP2 in the SNB19 human glioblastoma cell line revealed that IGFBP2 enhances the invasiveness of these cells by up-regulating expression of invasion-associated gene products, such as extracellular matrix-degrading protease, MMP-2 (Wang et al., 2003). We compared the expression profiles of two human glioblastoma cell lines, U251 and YKG-1, in the presence and absence of shRNA-induced silencing of IGFBP2 expression (Fukushima et al., 2007). In both cell lines, expression levels of various genes were altered by IGFBP2 knockdown without apparent alteration of IGF signaling, suggesting that IGFBP2 influences transcriptional regulation of many genes in glioblastoma cells independent of IGF signaling. Among the genes influenced by IGFBP2 silencing, the CD24 gene was identified as a candidate downstream target of IGFBP2-induced signaling, and subsequent analysis revealed that 
CD24 is critically involved in the invasiveness of U251 and YKG-1 cells (Fukushima et al., 2007). CD24 is a heavily glycosylated, cell surface, glycosylphosphatidylinositol-anchored protein (Kristiansen et al., 2004). While the precise mechanism by which CD24 induces cellular invasion is unclear, CD24 has been shown to recruit adhesion molecules to lipid rafts, thereby contributing to tumor cell migration, dissemination, and metastasis (Baumann et al., 2005; Runz et al., 2008). Of interest is a recent observation that a splice variant of GLI1, truncated GLI1 (tGLI1), which is highly expressed in glioblastoma cells but not in normal cells, induces cellular migratory and invasive capabilities via upregulaton of CD24 in U87 glioblastoma cells (Lo et al., 2009). As mentioned above, Hedgehog-GLI1 signaling is involved in glioma cell growth, expansion of GSC and induction of IGFBP2 expression (Clement et al., 2007; Villani et al., 2010). Therefore, Hedgehog-GLI1/IGFBP2/CD24 signaling may play a pivotal role in the invasive growth of glioblastoma cells.

The NF-KB pathway is another important candidate for the signaling involved in IGFBP2induced phenotypes. In fact, NF-kB signaling is activated in glioblastomas and involved in invasion and angiogenesis of glioma cells (Wang et al., 2004; Li et al., 2007). While NF-kB is suggested to regulate IGFBP2 gene expression in response to tissue injury (Cazals et al., 1999), intracellular IGFBP2 itself is involved in the regulation of NF-kB signaling via binding to invasion inhibitory protein 45 (IIp45, also named migration and invasion inhibitor protein MIIP), which was identified by a yeast two-hybrid assay (Song et al., 2003). The IIp45 gene is located on chromosome 1p36 (Song et al., 2003), a region that is frequently deleted in oligodendrogliomas and occasionally deleted in astrocytomas (Smith et al., 1999). Decreased IIp45/MIIP levels were also observed in 15\% of glioblastoma cases (Song et al., 2003). IIp45/MIIP binds to the RGD motif of IGFBP2 and inhibits the interaction between IGFBP2 and integrin, which eventually may inhibit the expression of transcriptional NF- $\mathrm{kB}$ and its downstream genes involved in invasive glioma cell growth (Song et al., 2003). It may be possible that upregulated NF-kB in the absence of IIp45/MIIP also stimulates IGFBP2 transcription and eventually establishes an autocrine stimulation circuit for invasive growth. Moreover, recent studies have indicated that IIp45/MIIP also interacts with intracellular proteins, such as Cdc20 and histon deacetylase 6 (HDAC6), and inhibits glioma cell proliferation and migration (Ji et al., 2010; Wu et al., 2010). Therefore, interaction between IIp45/MIIP and intracellular IGFBP2 may occur in glioblastoma cells, which may attenuate the function of IIp45/MIIP and thereby may enhance the cellular proliferation and migration.

We summarize hypothetical functions of IGFBP2 in the invasive growth of glioblastoma cells in Figure 2.

\subsubsection{IGFBP2 as a therapeutic target for high-grade gliomas}

We have shown above that IGFBP2 can provide crucial signaling during glioma development and can exhibit malignant phenotypes of glioblastoma. As such, IGFBP2 and its downstream targets may reasonably serve as novel therapeutic targets for glioblastoma. However, there have been limited attempts to target IGFBP2 for in vivo glioblastoma treatments. Moore et al. (2009) examined the effect of antisense IGFBP2 in vivo using PDGFB-induced glioma in Ink4a-Arf-null mice, and found that the inhibition of IGFBP2 expression confers a survival benefit. Therefore, IGFBP2 is a potential therapeutic target for Ink4a-Arf-dleted gliomas, such as anaplastic oligodendroglioma and glioblastoma (Moore et al., 2009). 
As a downstream molecule of IGFBP2 involved in invasiveness of glioblastoma cells, CD24 may also serve as a molecular target for glioblastoma treatment. Targeting CD24 by monoclonal antibodies, small interfering RNA or shRNA has been reported in xenograft models of human colorectal cancer, pancreatic cancer and ovarian cancer cell lines (Sagiv et al., 2008; Su et al., 2009). In those studies, retardation of tumorigenicity and significant reduction of tumor growth were observed in vivo, indicating that CD24 is a promising therapeutic target for treatment of cancer. As glioblastomas abundantly express CD24 as well as IGFBP2 (Fukushima et al., 2007), we suggest that targeting CD24 may be a potential therapeutic approach against glioblastoma.

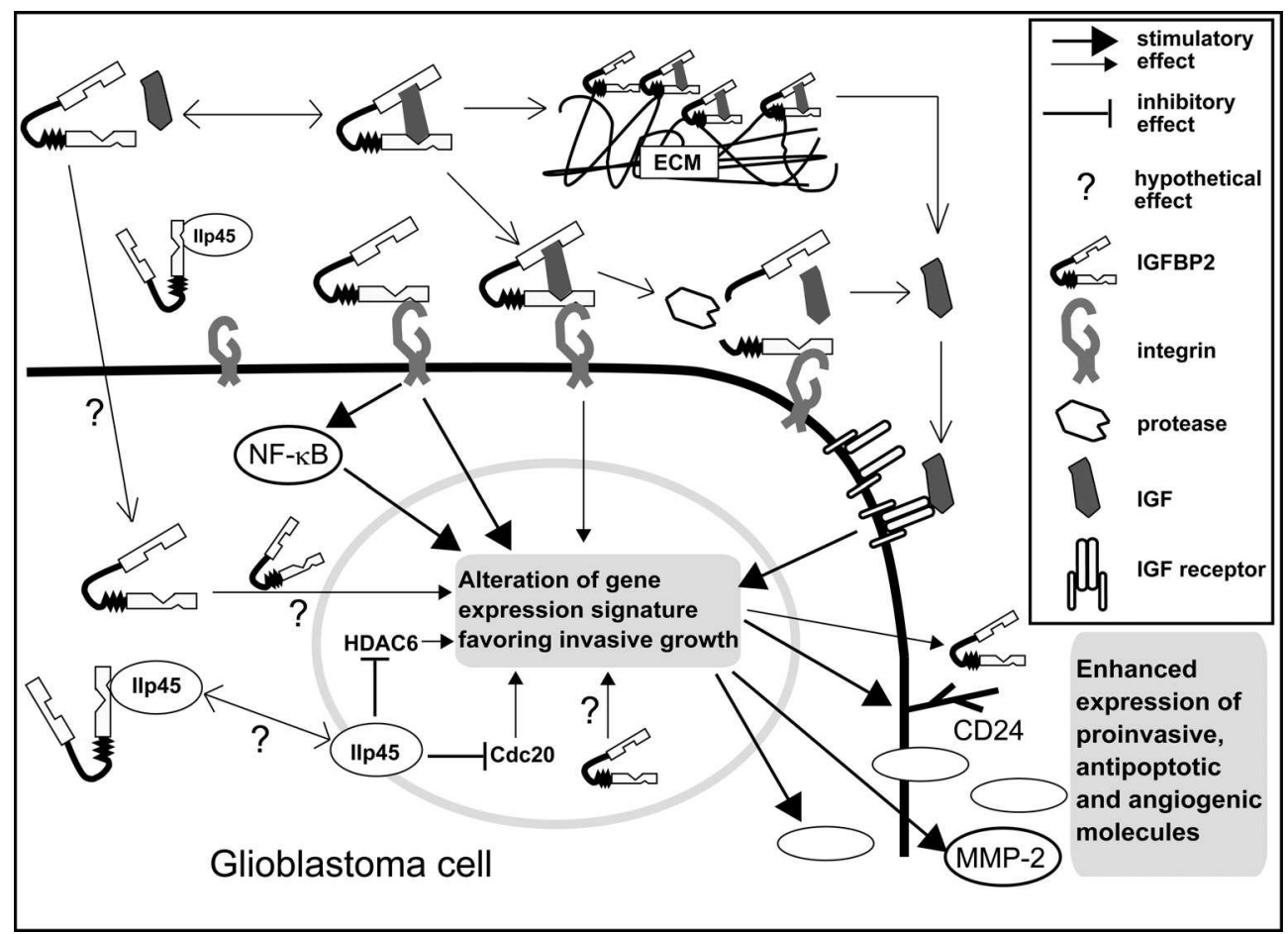

Fig. 2. Roles for IGFBP2 in the establishment of malignant phenotypes of glioblastoma cells. Both IGF-dependent and IGF-independent effects of IGFBP2 have been proposed. Integrinmediated outside-in signaling and NF- $\mathrm{kB}$ signaling appear to be involved in the IGFBP2induced effects, which eventually result in enhanced expression of proinvasive molecules, such as CD24 and MMP-2. While IIp45/MIIP may inhibit binding of IGFBP2 to integrin, it is possible to hypothesize that excess intracellular (intranuclear) IGFBP2 may suppress the inhibitory effects of IIp45/MIIP on Cdc20 and/or HDAC6-mediated cellular growth and migration. The upregulated NF-kB signaling enhances the expression of IGFBP2. Hypoxic microenvironment, loss of PTEN function and Hedgehog-GLI1 signaling might also be involved in the enhanced IGFBP2 expression in glioblastoma cells. Functions of intracellular and intranuclear IGFBP2 remain to be elucidated. ECM, extracellular matrix. 
IGFBP2 may also be an attractive marker to influence glioblastoma treatment strategy decisions. Since high IGFBP2 levels serve as a marker for loss of PTEN function and PI3K/Akt activation, the clinical data linking IGFBP2 expression to poor prognosis may be due, at least in part, to the loss of PTEN function, which is well known to lead to aggressive behavior of gliomas (Levitt et al., 2005; Mehrian-Shai, 2007). Therefore, measurements of IGFBP2 expression levels may be useful for estimating the functional PTEN status and $\mathrm{PI} 3 \mathrm{~K} /$ Akt activation levels in glioma, which in turn may be beneficial for organizing specific treatment strategies for each glioma case (Gonzalez \& de Groot, 2008). Moreover, recent study suggests that IGFBP2 expression level may be a marker for DNA hypermethylation profiles in gliomas (Zheng et al., 2011).

\section{Conclusion}

IGFBP2 is a pleiotropic protein that appears to be involved in many aspects of physiological and pathological processes and shows both positive and negative effects. Even in cancers, opposite effects of IGFBP2 are observed. For example, the growth of colorectal adenomas induced by chemical carcinogens in mice was inhibited upon crossing with IGFBP2 transgenic mice (Diehl et al., 2008). In contrast, IGFBP2 exerts oncogenic effects in brainspecific transgenic mice (Dunlap et al., 2007; Moore et al., 2009). Thus, IGFBP2 shows both negative and positive effects on tumor growth, and these differences are probably dependent on cell type and pericellular environment. Despite the diverse effects of IGFBP2 on the biological behaviors of cancers, it has been clearly demonstrated that IGFBP2 is overexpressed in a wide variety of human malignancies, and evidence is rapidly accumulating to indicate that IGFBP2 is significantly involved in the progression of glioma and confers malignant phenotypes of glioblastoma cells. To clarify the molecular mechanisms underlying the effects of IGFBP2 on gliomas, not only the pericellular IGFdependent and IGF-independent functions but also the functions of intracellular IGFBP2 should be defined (Figure 2). Additional information concerning the factors that directly regulate IGFBP2 overexpression in gliomas and those that are critically involved in the IGFBP2-mediated malignant features of glioblastoma cells is required and may lead to new therapeutic avenues for one of the most treatment-resistant human tumors.

\section{Acknowledgment}

We thank Drs. Makiko Kawaguchi, Yukihiro Haruyama and Hideo Takeshima for their valuable suggestions and Ms. Yasuko Tobayashi for her skillful technical assistance in our project. This work was supported in part by Grant-in-Aid for Scientific Research no. 20390114 (H. Kataoka) and for Young Scientists no. 22790384 (T. Fukushima) from the Ministry of Education, Science, Sports and Culture, Japan. The authors disclose no conflicts.

\section{References}

Baumann, P., Cremers, N., Kroese, F., Orend, G., Chiquet-Ehrismann, R., Uede, T., Yagita, H. \& Sleeman, J.P. (2005). CD24 expression causes the acquisition of multiple cellular properties associated with tumor growth and metastasis. Cancer Research, Vol.65, No.23, pp. 10783-10793, ISSN 0008-5472 
Bunn, R.C., John L. \& Fowlkes, J.L. (2003). Insulin-like growth factor-binding protein proteolysis. Trends in Endocrinology and Metabolism, Vol.14, No.4, pp. 174-181, ISSN 1043-2760

Busund, L.T., Richardsen, E., Busund, R., Ukkonen, T., Bjornsen, T., Busch, C. \& Stalsberg, H. (2005). Significant expression of IGFBP2 in breast cancer compared with benign lesions. Journal of Clinical Pathology, Vol.58, No.4, pp. 361-366, ISSN 0021-9746

Blum, W.F., Horn, N., Kratzsch, J., Jørgensen, J.O., Juul, A., Teale, D., Mohnike, K. \& Ranke, M.B. (1993). Clinical studies of IGFBP-2 by radioimmunoassay. Growth Regulation, Vol.3, No.1, pp.100-104, ISSN 0956-523X

Carmeliet, P., Dor, Y., Herbert, J.M., Fukumura, D., Brusselmans, K., Dewerchin, M., Neeman, M., Bono, F., Abramovitch, R., Maxwell, P., Koch, C.J., Ratcliffe, P., Moons, L., Jain, R.K., Collen, D. \& Keshert, E. (1998) Role of HIF-1a in hypoxiamediated apoptosis, cell proliferation and tumour angiogenesis. Nature, Vol.394, No.6692, pp. 485-490, ISSN 0028-0836

Cazals, V., Nabeyrat, E., Corroyer, S., de Keyzer, Y. \& Clement, A. (1999). Role for NF-kappa $\mathrm{B}$ in mediating the effects of hyperoxia on IGF-binding protein 2 promoter activity in lung alveolar epithelial cells. Biochemical and Biophysical Research Communications, Vol.1448, No.3, pp. 349-362, ISSN 0006-3002

Clarke, J., Butowski, N. \& Chang S. (2010). Recent advances in therapy for glioblastoma. Archives of Neurology, Vol.67, No.3, pp. 279-283, ISSN 0003-9942

Clement, V., Sanchez, P., de Tribolet, N., Radovanovic, I., Ruiz, I. \& Altaba, A. (2007). HEDGEHOG-GLI1 signaling regulates human glioma growth, cancer stem cell selfrenewal, and tumorigenicity. Current Biology, Vol.17, No.2, pp. 165-172, ISSN 09609822

Clemmons, D.R. (1998). Role of insulin-like growth factor binding proteins in controlling IGF actions. Molecular and Cellular Endocrinology, Vol.140, No.1-2, pp. 19-24, ISSN 0303-7207

Cohen, P., Peehl, D. M., Graves, H.C., Rosenfeld, R.G. \& Rosenfeld, R. G. (1994). Biological effects of prostate specific antigen as an insulin-like growth factor binding protein-3 protease. Journal of Endocrinology, Vol.142, No.3, pp. 407-415, ISSN 0022-0795

de Bont, J.M., van Doorn, J., Reddingius, R.E., Graat, G.H., Passier, M.M., den Boer, M.L. \& Pieters, R. (2008). Various components of the insulin-like growth factor system in tumor tissue, cerebrospinal fluid and peripheral blood of pediatric medulloblastoma and ependymoma patients. International Journal of Cancer, Vol.123, No.3, pp. 594-600, ISSN 0020-7136

de Groot, J.F., Fuller, G., Kumar, A.J., Piao, Y., Eterovic, K., Ji ,Y. \& Conrad, C.A. (2010). Tumor invasion after treatment of glioblastoma with bevacizumab: radiographic and pathologic correlation in humans and mice. Neuro-Oncology, Vol.12, No.3, pp.233-242, ISSN 1522-8517

DeMambro, V.E., Clemmons, D.R., Horton, L.G., Bouxsein, M.L., Wood, T.L., Beamer, W.G., Canalis, E. \& Rosen, C.J. (2008). Gender-specific changes in bone turnover and skeletal architecture in igfbp-2-null mice. Endocrinology, Vol.149, No.5, pp. 20512561, ISSN 0013-7227 
Diehl, D., Hessel, E., Oesterle, D., Renner-Müller, I., Elmlinger, M., Langhammer, M., Göttlicher, M., Wolf, E., Lahm, H. \& Hoeflich, A. (2008). IGFBP-2 overexpression reduces the appearance of dysplastic aberrant crypt foci and inhibits growth of adenomas in chemically induced colorectal carcinogenesis. International Journal of Cancer, Vol.124, No.9, pp. 2220-2225, ISSN 0020-7136

Dunlap, S.M., Celestino, J., Wang, H., Jiang, R., Holland, E.C., Fuller, G.N. \& Zhang, W. (2007). Insulin-like growth factor binding protein 2 promotes glioma development and progression. Proceedings of the National Academy of Sciences of the United States of America Vol.104, No.28, pp. 11736-11741, ISSN 0027-8424

Elmlinger, M.W., Deininger, M.H., Schuett, B.S., Meyermann, R., Duffner, F., Grote, E.H. \& Ranke, M.B. (2001). In Vivo expression of insulin-like growth factor-binding protein-2 in human gliomas increases with the tumor grade. Endocrinology, Vol.142, No.4, pp.1652-1658, ISSN 0013-7227

Feldser, D., Agani F., Iyer, N.V., Pak, B., Ferreira, G. \& Semenza, G.L. (1999). Reciprocal positive regulation of hypoxia-inducible factor 1alpha and insulin-like growth factor 2. Cancer Research, Vol.59, No.16, pp. 3915-3918, ISSN 0008-5472

Firth, S.M. \& Baxter, R.C. (2002). Cellular Actions of the Insulin-Like Growth Factor Binding Proteins. Endocrine Reviews, Vol.23, No.6, pp. 824-854, ISSN 0163-769X

Fowlkes, J.L., Serra, D.M., Bunn, R.C., Thrailkill, K.M., Enghild, J.J. \& Nagase, H. (2004). Regulation of insulin-like growth factor (IGF)-I action by matrix metalloproteinase3 involves selective disruption of IGF-I/IGF-binding protein-3 complexes. Endocrinology, Vol.145, No.2, pp. 620-626, ISSN 0013-7227

Fukushima, T. \& Kataoka, H. (2007). Roles of insulin-like growth factor binding protein-2 (IGFBP-2) in glioblastoma. Anticancer Research, Vol.27, No.6A, pp. 3685-3692, ISSN 0250-7005

Fukushima, T., Tezuka, T., Shimomura, T., Nakano, S. \& Kataoka, H. (2007), Silencing of insulin-like growth factor-binding protein-2 in human glioblastoma cells reduces both invasiveness and expression of progression-associated gene CD24. Journal of Biological Chemistry, Vol. 282, No.25, pp. 18634-18644, ISSN 0021-9258

Fuller, G. N., Rhee, C. H., Hess, K. R., Caskey, L. S., Wang, R., Bruner, J. M., Yung, W. K., \& Zhang, W. (1999). Reactivation of insulin-like growth factor binding protein 2 expression in glioblastoma multiforme: a revelation by parallel gene expression profiling. Cancer Research, Vol.59, No.17, pp. 4228-4232, ISSN 0008-5472

Garner, C.P., Ding, Y.C., John, E.M., Ingles, S.A., Olopade, O.I., Huo, D., Adebamowo, C., Ogundiran, T. \& Neuhausen, S.L.(2008). Genetic variation in IGFBP2 and IGFBP5 is associated with breast cancer in populations of African descent. Human Genetics, Vol.123, No.3, pp. 247-255, ISSN 0340-6717

Godard, S., Getz, G., Delorenzi, M., Farmer, P., Kobayashi, H., Desbaillets, I., Nozaki, M., Diserens, A.C., Hamou, M.F., Dietrich, P.Y., Regli, L., Janzer, R.C., Bucher, P., Stupp, R., de Tribolet, N., Domany, E. \& Hegi, M.E. (2003). Classification of human astrocytic gliomas on the basis of gene expression: a correlated group of genes with angiogenic activity emerges as a strong predictor of subtypes. Cancer Research, Vol.63, No.20, pp. 6613-6625, ISSN 0008-5472 
Gonzalez, J. \& de Groot, J. (2008) Combination therapy for malignant glioma based on PTEN status. Expert Review of Anticancer Therapy, Vol.8, No.11, pp. 1767-1779, ISSN 14737140

Grimberg, A., Coleman, C.M., Shi, Z., Burns, T.F., MacLachlan, T.K., Wang, W. \& El-Deiry, W.S. (2006). Insulin-like growth factor factor binding protein-2 is a novel mediator of p53 inhibition of insulin-like growth factor signaling. Cancer Biology $\mathcal{E}$ Therapy, Vol.5, No.10, pp.1408-1414, ISSN 1538-4047

Harris, P.J., Takebe, N. \& Ivy, S.P. (2010). Molecular conversations and the development of the hair follicle and basal cell carcinoma. Cancer Prevention Research, Vol.3, No.10, pp. 1217-1221, ISSN 1940-6207

Hedbacker, K., Birsoy, K., Wysocki, R.W., Asilmaz, E., Ahima, R.S., Farooqi, I.S. \& Friedman, J.M.(2010). Antidiabetic effects of IGFBP2, a leptin-regulated gene. Cell Metabolism, Vol.11, No.1, pp. 11-22, ISSN 1550-4131

Hoeflich, A., Reisinger, R., Schuett, B.S., Elmlinger, M.W., Russo, V.C., Vargas, G.A., Jehle, P.M., Lahm, H., Renner-Muller, I. \& Wolf, E. (2004). Peri/nuclear localization of intact insulin-like growth factor binding protein-2 and a distinct carboxyl-terminal IGFBP-2 fragment in vivo. Biochemical and Biochemical and Biophysical Research Communications, Vol.324, No.2, pp.705-710, ISSN 0006-291X

Hsieh, D., Hsieh, A., Stea, B. \& Ellsworth, R. (2010). IGFBP2 promotes glioma tumor stem cell expansion and survival. Biochemical and Biochemical and Biophysical Research Communications, Vol.397, No.2, pp.367-372, ISSN 0006-291X

Hwa, V., Oh, Y. \& Rosenfeld, R.G. (1999). The insulin-like growth factor-binding protein (IGFBP) superfamily. Endocrinology Review, Vol.20, No.6, pp. 761-787, ISSN 0163$769 X$

Ji, P., Smith, S.M., Wang, Y., Jiang, R., Song, S.W., Li, B., Sawaya, R., Bruner, J.M., Kuang, J., Yu, H., Fuller, G.N. \& Zhang, W. (2010). Inhibition of gliomagenesis and attenuation of mitotic transition by MIIP. Oncogene, Vol.29, No.24, pp. 3501-3508, ISSN 0950-9232

Jiang, R., Mircean, C., Shmulevich, I., Cogdell, D., Jia, Y., Tabus, I., Aldape, K., Sawaya, R., Bruner, J.M., Fuller, G.N. \& Zhang, W. (2006). Pathway alterations during glioma progression revealed by reverse phase protein lysate arrays. Proteomics, Vol.6, No.10, pp. 2964-2971, ISSN 1615-9853

Kelley, K.M., Schmidt, K.E., Berg, L., Sak, K., Galima, M.M., Gillespie ,C., Balogh, L., Hawayek, A., Reyes, J.A. \& Jamison, M. (2002). Comparative endocrinology of the insulin-like growth factor-binding protein. The Journal of Endocrinology, Vol.175, No.1, pp. 3-18, ISSN 0022-0795

Kristiansen, G., Sammar, M. \& Altevogt, P. (2004). Tumour biological aspects of CD24, a mucin-like adhesion molecule. Journal of Molecular Histology, Vo.35, No.3 , pp. 255264, ISSN 1567-2379

Lancaster, J. M., Sayer, R. A., Blanchette, C., Calingaert, B., Konidari, I., Gray, J., Schildkraut, J., Schomberg, D. W., Marks, J. R., \& Berchuck, A. (2006). High expression of insulin-like growth factor binding protein-2 messenger RNA in epithelial ovarian cancers produces elevated preoperative serum levels. International Journal of Gynecological Cancer, Vol.16, No.4, pp. 1529-1535, ISSN 1048-891X 
Lee, C.Y. \& Rechler, M.M. (1996). Proteolysis of insulin-like growth factor (IGF)-binding protein-3 (IGFBP-3) in 150-kilodalton IGFBP complexes by a cation-dependent protease activity in adult rat serum promotes the release of bound IGF-I. Endocrinology, Vol.137, No.5, pp. 2051-2058, ISSN 0013-7227

Lee, D.Y., Kim, S.J. \& Lee, Y.C. (1999). Serum insulin-like growth factor (IGF)-I and IGFbinding proteins in lung cancer patients. Journal of Korean Medical Science, Vol.14, No.4, pp. 401-404, ISSN 1011-8934

Lee, W.H., Michels, K.M. \& Bondy, C.A. (1993). Localization of insulin growth factor binding protein-2 messenger RNA during postnatal brain development: correlation with insulin-like growth factors I and II. Neuroscience, Vol.53, No.1, pp. 251-265, ISSN 251-265

Levitt, R.J., Georgescu, M.M. \& Pollak, M. (2005). PTEN-induction in U251 glioma cells decreases the expression of insulin-like growth factor binding protein-2. Biochemical and Biophysical Research Communications, Vol.336, No.4, pp. 1056-1061, ISSN 0006291X

Li, L., Gondi, C.S., Dinh, D.H., Olivero, W.C., Gujrati, M. \& Rao, J.S. (2007). Transfection with anti-p65 intraantibody suppresses invasion and angiogenesis in glioma cells by blocking nuclear factor- $\mathrm{KB}$ transcriptional activity. Clinical Cancer Research, Vol.13, No.7, pp. 2178-2190, ISSN 1078-0432

Li, Z. \& Picard, F. (2010). Modulation of IGFBP2 mRNA expression in white adipose tissue upon aging and obesity. Hormone and Metabolic Research, Vol.42, No.11, pp. 787-791, ISSN 0018-5043

Lin, Y., Jiang, T., Zhou, K., Xu, L,. Chen, B., Li, G., Qiu, X., Jiang, T., Zhang, W. \& Song, S.W. (2009). Plasma IGFBP-2 levels predict clinical outcomes of patients with high-grade gliomas. Neuro-Oncology, Vol.11, No.5, pp. 468-476, ISSN 1522-8517

Lo, H.W., Zhu, H., Cao, X., Aldrich, A. \& Ali-Osman, F. (2009) A novel splice variant of GLI1 that promotes glioblastoma cell migration and invasion. Cancer Research, Vol.69, No.17, pp. 6790-6798, ISSN 0008-5472

Mark, S., Kubler, B., Honing, S., Oesterreicher, S., John, H., Braulke ,T., Forssmann, W.G. \& Standker, L. (2005). Diversity of human insulin-like growth factor (IGF) binding protein-2 fragments in plasma: primary structure, IGF-binding properties, and disulfide bonding pattern. Biochemistry, Vol.44, No.9, pp. 3644-3652, ISSN 0006-2960

Mehrian-Shai ,R., Chen, C.D., Shi, T., Horvath, S., Nelson, S.F., Reichardt, J.K. \& Sawyers, C.L. (2007). Insulin growth factor-binding protein 2 is a candidate biomarker for PTEN status and PI3K/Akt pathway activation in glioblastoma and prostate cancer. Proceedings of the National Academy of Sciences of the United States of America, Vol.104, No.13, pp. 5563-5568, ISSN 0027-8424

Migita, T., Narita, T., Asaka, R., Miyagi, E., Nagano, H., Nomura, K., Matsuura, M., Satoh, Y., Okumura, S., Nakagawa, K., Seimiya, H. \& Ishikawa, Y. (2010). Role of insulinlike growth factor binding protein 2 in lung adenocarcinoma: IGF-independent antiapoptotic effect via caspase-3. American Journal of Pathology, Vol.176, No.4, pp. 1756-1766, ISSN 0002-9440 
Mishra, L., Bass, B., Ooi, B. S., Sidawy, A., \& Korman, L. (1998), Role of insulin-like growth factor-I (IGF-I) receptor, IGF-I, and IGF binding protein-2 in human colorectal cancers. Growth Hormone \& IGF Research, Vol.8, No.6, pp.473-479, ISSN 1096-6374

Moore, L.M., Holmes, K.M., Smith, S.M., Wu, Y., Tchougounova, E., Uhrbom, L., Sawaya, R., Bruner, J.M., Fuller, G.N. \& Zhang, W. (2009). IGFBP2 is a candidate biomarker for Ink4a-Arf status and a therapeutic target for high-grade gliomas. Proceedings of the National Academy of Sciences of the United States of America, Vol.106, No.39, pp. 1667516679, ISSN 0027-8424

Mouhieddine, O.B., Cazals, V., Kuto, E., Le, Bouc, Y. \& Clement, A. (1996). Glucocorticoidinduced growth arrest of lung alveolar epithelial cells is associated with increased production of insulin-like growth factor binding protein-2. Endocrinology, Vol.137, No.1, pp.287-295, ISSN 0013-7227

Nakamura, M., Miyamoto, S., Maeda, H., Ishii, G., Hasebe, T., Chiba, T., Asaka, M. \& Ochiai, A. (2005). Matrix metalloproteinase-7 degrades all insulin-like growth factor binding proteins and facilitates insulin-like growth factor bioavailability. Biochem Biophys Research Communications, Vol.333, No.3, pp. 1011-1016, ISSN 0006-291X

Nordqvist, A. C. \& Mathiesen, T. (2002). Expression of IGF-II, IGFBP-2, -5, and -6 in meningiomas with different brain invasiveness. Journal of Neurooncology, Vol.57, No.1, pp. 19-26, ISSN 0167-594X

Nordqvist, A.C., Peyrard,M., Pettersson, H., Mathiesen, V.T., Collins, P., Dumanski, J.P. \& Schaffing, M. (1997). A high ratio of insulin-like-growth factor Il/insulin-like growth factor binding protein 2 messenger RNA as a marker for anaplasia in meningiomas. Cancer Research, Vol.57, No.13, pp.2611-2614, ISSN 0008-5472

Pekonen, F., Nyman, T., Ilvesmäki, V. \& Partanen, S. (1992). Insulin-like growth factor binding proteins in human breast cancer tissue. Cancer Research, Vol.52. No.19, pp. 5204-5207, ISSN 0008-5472

Perks, C.M., Vernon, E.G., Rosendahl, A.H., Tonge, D. \& Holly, J.M. (2007). IGF-II and IGFBP-2 differentially regulate PTEN in human breast cancer cells. Oncogene Vol.26, No.40, pp. 5966-5972, ISSN 0950-9232

Rickman, D. S., Bobek, M. P., Misek, D. E., Kuick, R., Blaivas, M., Kurnit, D. M., Taylor, J. \& Hanash, S. M. (2001). Distinctive molecular profiles of high-grade and low-grade gliomas based on oligonucleotide microarray analysis. Cancer Research, Vol.61, No.18, pp.6885-6891, ISSN 0008-5472

Runz, S., Mierke, C.T., Joumaa, S., Behrens, J., Fabry, B. \& Altevogt, P. (2008). CD24 induces localization of beta1 integrin to lipid raft domains. Biochemical and Biophysical Research Communications, Vol.365, No.1, pp.35-41, ISSN 0006-291X

Russo, V.C., Schütt, B.S., Andaloro, E., Ymer, S.I., Hoeflich, A., Ranke, M.B., Bach, L.A. \& Werther, G.A. (2005). Insulin-like growth factor binding protein-2 binding to extracellular matrix plays a critical role in neuroblastoma cell proliferation, migration, and invasion. Endocrinology, Vol.146, No.10, pp. 4445-4455, ISSN 00137227

Sallinen, S. L., Sallinen, P. K., Haapasalo, H. K., Helin, H. J., Helen, P. T., Schraml, P., Kallioniemi, O. P. \& Kononen, J. (2000). Identification of differentially expressed 
genes in human gliomas by DNA microarray and tissue chip techniques. Cancer Research, Vol.60, No.23, pp. 6617-6622, ISSN 0008-5472

Sagiv, E., Starr, A., Rozovski, R., Altevogt, P., Wang, T. \& Arber, N. (2008). Targeting CD24 for treatment of colorectal and pancreatic cancer by monoclonal antibodies or small interfering RNA. Cancer Research, Vol.68, No.8, pp. 2803-2812, ISSN 0008-5472

Santosh, V., Arivazhagan, A., Sreekanthreddy, P., Srinivasan, H., Thota, B., Srividya, M.R., Vrinda, M., Sridevi, S., Shailaja, B.C., Samuel, C., Prasanna, K.V., Thennarasu, K., Balasubramaniam, A., Chandramouli, B.A., Hegde, A.S., Somasundaram, K., Kondaiah, P. \& Rao, M.R. (2010). Grade-specific expression of insulin-like growth factor-binding proteins-2, -3 , and -5 in astrocytomas: IGFBP-3 emerges as a strong predictor of survival in patients with newly diagnosed glioblastoma. Cancer Epidemiology, Biomarkers \& Prevention, Vol.19, No.6, pp. 1399-1408, ISSN 1055-9965

Schutt, B.S., Langkamp, M., Rauschnabel, U., Ranke, M.B. \& Elmlinger, M.W. (2004). Integrin-mediated action of insulin-like growth factor binding protein-2 in tumor cells. Journal of Molecular Endocrinology, Vol.32, No.3, pp. 859-868, ISSN 09525041

Schwander, J. \& Mary, J.L. (1993). The RIA for IGFBP-2 in man--a meagre catch?, Growth Regulation, Vol.3, No.1, pp. 104-108, ISSN 0956-523X

Smith, J.S., Alderete, B., Minn, Y., Borell, T.J,. Perry, A., Mohapatra, G., Hosek, S.M., Kimmel, D., O'Fallon, J., Yates, A., Feuerstein, B.G., Burger, P.C., Scheithauer, B.W. \& Jenkins, R.B. (1999). Localization of common deletion regions on $1 p$ and $19 q$ in human gliomas and their association with histological subtype. Oncogene, Vol.18, No.28, pp. 4144-4152, ISSN 0950-9232

Song, S.W., Fuller, G.N., Khan, A., Kong, S., Shen, W., Taylor, E., Ramdas, L., Lang, F. F. \& Zhang, W. (2003) IIp45, an insulin-like growth factor binding protein 2 (IGFBP-2) binding protein, antagonizes IGFBP-2 stimulation of glioma cell invasion. Proceedings of the National Academy of Sciences of the United States of America, Vol.100, No.24, pp. 13970-13975, ISSN 0027-8424

Su, D., Deng, H., Zhao, X., Zhang, X., Chen, L., Chen, X., Li, Z., Bai, Y., Wang, Y., Zhong, Q., Yi, T., Qian, Z. \& Wei, Y. (2009). Targeting CD24 for treatment of ovarian cancer by short hairpin RNA. Cytotherapy, Vo.11, No.5, pp. 642-652, ISSN 1465-3249

Sulis, M.L. \& Parsons, R. (2003). PTEN: from pathology to biology. Trends in Cell Biology, Vol.13, No.9, pp. 478-483, ISSN 0962-8924

van den Beld, A.W., Blum, W.F., Pols, H.A., Grobbee, D.E. \& Lamberts, S.W. (2003). Serum insulin-like growth factor binding protein-2 levels as an indicator of functional ability in elderly men. European Journal of Endocrinology, Vol.148, No.6, pp. 627-634, ISSN 0804-4643

Villani, R.M., Adolphe, C., Palmer, J., Waters, M.J. \& Wainwright, B.J. (2010) Patched1 inhibits epidermal progenitor cell expansion and basal cell carcinoma formation by limiting Igfbp2 activity. Cancer Prevention Research, Vol.3, No.10, pp. 1222-1234, ISSN 1940-6207

Wang, G.K., Hu, L., Fuller, G.N. \& Zhang, W. (2006). An interaction between insulin-like growth factor-binding protein 2 (IGFBP2) and integrin alpha5 is essential for 
IGFBP2-induced cell mobility. Journal of Biological Chemistry, Vol.281, No.20, pp. 14085-14091, ISSN 0021-9258

Wang, H., Shen, W., Huang, H., Hu, L., Ramdas, L., Zhou, Y.H., Liao, W.S., Fuller, G.N. \& Zhang, W. (2003). Insulin-like growth factor binding protein 2 enhances glioblastoma invasion by activating invasion-enhancing genes. Cancer Research, Vol.63, No.15, pp. 4315-4321, ISSN 0008-5472

Wang, H., Wang, H., Zhang, W., Huang, H.J., Liao, W.S.L. \& Fuller, G.N. (2004). Analysis of the activation status of Akt, NFKB, and Stat3 in human diffuse gliomas. Laboratory Investigation, Vol.84, No. 8, pp.941-951, ISSN 0023-6837

Wood, T.L., Rogler, L.E., Czick, M.E., Schuller, A.G. \& Pintar, J.E.. (2000). Selective alterations in organ sizes in mice with a targeted disruption of the insulin-like growth factor binding protein-2 gene. Journal of Molecular Endocrinology, Vol.14, No.9, pp. 1472-1482, ISSN 0952-5041

Wood, T.L., Rogler, L., Streck, R.D., Cerro, J., Green, B., Grewal, A. \& Pintar, J.E. (1993). Targeted disruption of IGFBP-2 gene. Growth Regulation, Vol.3, No.1, pp. 5-8, ISSN 0956-523X

Wood, T. L., Streck, R. D. \& Pintar, J. E. (1992). Expression of the IGFBP-2 gene in postimplantation rat embryos. Development, Vol.114, No.1, pp. 59-66, ISSN 0950-1991

Wu, Y., Song, S.W., Sun, J., Bruner, J.M., Fuller, G.N. \& Zhang, W. (2010). IIp45 inhibits cell migration through inhibition of HDAC6. Journal of Biological Chemistry, Vol.285, No.6, pp. 3554-3560, ISSN 0021-9258

Zheng, B., Clark,e J.B., Busby, W.H., Duan, C., Clemmons, D.R. (1998). Insulin-like growth factor-binding protein-5 is cleaved by physiological concentrations of thrombin. Endocrinology, Vol.139, No.4, pp. 1708-1714. ISSN 0013-7227

Zheng, S., Houseman, E.A., Morrison, Z., Wrensch, M.R., Patoka, J.S., Ramos, C., HaasKogan, D.A., McBride, S., Marsit, C.J., Christensen, B.C., Nelson, H.H., Stokoe, D., Wiemels, J.L., Chang, S.M., Prados, M.D., Tihan, T., Vandenberg, S.R., Kelsey, K.T., Berger, M.S. \& Wiencke, J.K. (2011). DNA hypermethylation profiles associated with glioma subtypes and EZH2 and IGFBP2 mRNA expression. Neuro-Oncology, Vol.13, No.3, pp. 280-289, ISSN 1522-8517 


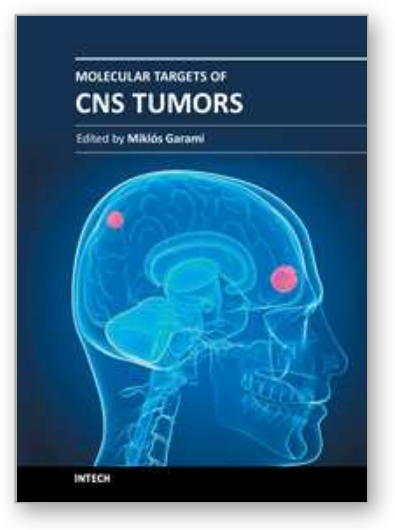

\author{
Molecular Targets of CNS Tumors \\ Edited by Dr. Miklos Garami
}

ISBN 978-953-307-736-9

Hard cover, 674 pages

Publisher InTech

Published online 22, September, 2011

Published in print edition September, 2011

Molecular Targets of CNS Tumors is a selected review of Central Nervous System (CNS) tumors with particular emphasis on signaling pathway of the most common CNS tumor types. To develop drugs which specifically attack the cancer cells requires an understanding of the distinct characteristics of those cells. Additional detailed information is provided on selected signal pathways in CNS tumors.

\title{
How to reference
}

In order to correctly reference this scholarly work, feel free to copy and paste the following:

Tsuyoshi Fukushima and Hiroaki Kataoka (2011). Insulin-Like Growth Factor Binding Protein-2: A Possible Regulator of Invasive Growth in Glioblastoma, Molecular Targets of CNS Tumors, Dr. Miklos Garami (Ed.), ISBN: 978-953-307-736-9, InTech, Available from: http://www.intechopen.com/books/molecular-targets-of-cnstumors/insulin-like-growth-factor-binding-protein-2-a-possible-regulator-of-invasive-growth-in-glioblastoma

\section{INTECH}

open science | open minds

\author{
InTech Europe \\ University Campus STeP Ri \\ Slavka Krautzeka 83/A \\ 51000 Rijeka, Croatia \\ Phone: +385 (51) 770447 \\ Fax: +385 (51) 686166 \\ www.intechopen.com
}

\author{
InTech China \\ Unit 405, Office Block, Hotel Equatorial Shanghai \\ No.65, Yan An Road (West), Shanghai, 200040, China \\ 中国上海市延安西路65号上海国际贵都大饭店办公楼405单元 \\ Phone: +86-21-62489820 \\ Fax: +86-21-62489821
}


(C) 2011 The Author(s). Licensee IntechOpen. This chapter is distributed under the terms of the Creative Commons Attribution-NonCommercialShareAlike-3.0 License, which permits use, distribution and reproduction for non-commercial purposes, provided the original is properly cited and derivative works building on this content are distributed under the same license. 